periods of freedom from recurrence. He believed that the operations for the complete extirpation of the caneerous uterus would soon drop out of surgical practice, as they had done in a past generation. The vaginal method appeared to be the best, but it was a poor best in immediatc and after results, and usnally necessitated leaving the tubes, or a great part of them, lest the pedicles on each sile should slip; and what probability was there, that organs, so continuons in structure with the uterus as these were, would be free from the disease? - British Med. Journ., Sept. 15, 1883.

\title{
Cancer of the Cervix and its Treatment.
}

Dr. A. WYNN WILLIAMS read a paper on this subject at the late meeting of the British Medical Association. There appears to him to be little or no difference between epithelioma of the cervix of the nterus and those forns of caneer known as medullary tumour growing from the same organ; the difference, if any, depending solely on the nature of the texture of the organ whence originating; the medullary tumour having its origin from the inner textures of the eervix; epithelioma, or the cauliflower growth, from its external covering.

Whenever we have any suspieion that suel a discase as cancer exists, no time should be lost in ascertaining whether or not such is the case. Thus, whenever a patient complains of continu ous pains in the back, extending down the thighs, especially the lcft, with irrcgular and profuse discharges from the uterus, together with discharges coming through the vagina, of a watery, sanious, and offensive character, she should be made to understand the absolute necessity there is to ascertain with certainty the nature of her malady, and of what vital importance it is to her, as the only hope of cure is in the early stage of the disease.

Whenever the disease has extended to the adjacent parts, such as the mucous mcmbrane of the vagina proper, or to the neighbouring glands, or when the uterus is firmly fixed, you must not expect to do mole than palliate the patient's sufferings ; when, however, the utcrus is partially fixed, without uleeration of the mucous membrane of the vagina, much may be done to prolong life.

When we have satisfied ourselves that a patient is suffering from eancer of the neck of the uterus; whether of an epitheliomatous or medullary character (practically there is no difference in the treatment), and the discase is confined to the uterus, we should proceed at once to get rid of as much of the diseased parts as is possible. This I do by means of the ecraseur, cautery-knife, scoop, scissors, and scalpel ; the patient reclining on her back, and under the influence of some anæstlietic.

In cases of epithelioma, or the cauliflower-growth, I remove the neck of the uterus with the ecraseur, taking as much off as I possibly can without cutting into Douglas's pouch. Having done this, I introduce a large-sized speeulum into the vagina, and apply the cautery to any bleeding points; removing at the same time, if necessary, with the cautery-knife, seissors, or sealpel, all diseased portions within reach-preferring the eautery-knife. I then apply a flat catery freely to the whole of the raw surface, to prevent hemorrhage, and also for the purpose of eausing a certain amount of slough. I then apply a plug of cottonwool smeared over with a solution of perchloride of iron and glycerine, fill the vagina with cotton-wool, and apply a T-bandage. 'Tlese plugs may bc left in for two days, then removed, and the vagina syringed with a weak solution of tincture of iodine and water three or four times a day until the slough has separated. When this has taken place, I apply to any suspicious-looking part a strong spirituous solution of bromine (one drachm of bromine to threc of spirit of wine), by meaus of a small pledget of cotton-wool. This is left in contact 
with the wound for three or four hours. By this time, the bromine will have all evaporated. Care must be taken to prevent the contact of the bromine with the wall of the vagina, which is best done by thin pledgets of wool saturated with a solution of earbonate of soda. After passing down the speculum a plug of simple wool, I place over all a piece of gutta-percha tissue, made into the shape of a ball with cotton-wool.

The separation of the slough, or melting away of the diseased tissues, is not completed under a week or ninc days. I may observe that bromine does not act as an ordinary eseharotie by simply charring, but dissolves animal matter when saturated with it. Whilst this sloughing or melting is going on, the vagina is syringed out three or four times a day with a weak solutiou of the tincture of iodine. When this is completed, a solution of bromine is substituted; two or three drops of the strong solution to half a pint of water. This process must be repeated again and again until all vestige of the discase is removed.

In the medullary form of cancer the disease is not so easily diagnosed, or brought under the notice of the physician so early, as in the epithelial form, owing to the abscnce, in the early stage of the disease, of the peculiarly thin, watery, offensive discharge. The discharge is often supposed to be inerely leucorrhasl, and the hemorrhage due to excess of menstruation. The physician is thus often not called in until the diseased mass is ulcerated and broken up into shreds. If a patient come to me when the disease exists only as a tumour iu the neck of the uterus, I rcmove the neck of the nterus with the ecraseur, and then dissect out any portion which might exist beyond the reach of the ecraseur. It is truly marvellous what a quantity of diseased tissue may be removed from within the uterus without any serious loss of blood.

Having removed all diseased portions as far as practicable, $I$ then treat the ease in the usual way with bromine. Should the tumour be broken up into shreds, and the mucous membrane of the vagina be still unimplicated, the case should not be given up as lopeless. By cureful manipulation with the instruments before mentioned, $I$ have cut away such a large portion of the diseased tissues as has enabled me to apply the strong bromine solution with success. In many of these cases, again, they only come before us as the raw bleeding surface of a broken-up medullary or epitheliomatous tunnour. Indeed, I am inclined to think that the so-called corroding ulcer is often nothing more. These ulcers are to be treated in the same manner as those caused by our own manipulations. Occasionally, when treating these cases, you will come on a hard solid portion. A few ycars ago, I was in the habit of injecting these with the bromine solution; but I rarely do this now, as it is not altogether unaccompanied by danger. I now proceed in a different manner. I pass a straight eautery-knife right through the hard mass, and, when the slough has separated, introduce a small pledget of cotton-wool saturated with the strong solution of bromine, or introduce it by means of cotton-wool wrapped round a vulcanite stem or sea-tangle. It is not very often that true scirrhus attacks the neck of the uterus; whenever it is met with, the tumour must either be injected with bromine or the neck of the uterus amputated, and then any stump that may be left treated with bromine in the usual way.-British Medical Journ., Sept. $15,1883$. 